\title{
ASSESSMENT OF THE CONSTITUTIONALITY OF PROBLEMS IN THE PROPERTY PROTECTION THROUGH THE MEANS OF CRIMINAL LEGISLATION OF REPUBLIC OF MOLDOVA
}

DOI: $10.47743 /$ rdc-2019-1-0003

Corina STRATAN, doctoral candidate, Doctoral School of Law, "Alexandru loan Cuza" University, lași, România.

\section{Abstract}

The property right is a fundamental right guaranteed both in Romania and in the Republic of Moldova by the higher law - the Constitution, that is why "No one may be expropriated except for reasons dictated by public necessity, as established by law and against just and appropriate compensation made in advance". By virtue of this constitutional guarantee the Criminal Code the only criminal law in the Republic of Moldova ensure an adequate protection of the property, whether it is public or private, through a unique system of regulations and sanctions. This article refers to the control of the constitutionality of the incriminating norms of the crimes against the property by the legal acts of the Constitutional Court, which is the only authority of constitutional jurisdiction. When exercising this control, the Court rules only on the conformity of the provisions criticized with the norms of the Constitution, and the referrals regarding the exceptions of unconstitutionality which concern not a normative but an exclusive act, its interpretation or application will be rejected as inadmissible and, this role will be attributed to the courts. However, in order to verify whether the rules under scrutiny comply with the constitutional provisions, the Court examining the complaint first makes clear the content of the provision, which is the exact meaning and then determines whether or not it is constitutional.

Keywords: Constitution, Constitutional Court, offenses against patrimony, referral regarding the exception of unconstitutionality, compliance, non-compliance with the constitutional norms, ruling, decision 
Property right - the fundamental right, guaranteed by the Constitution of the Republic of Moldova

The right of property, according to the Constitution of the Republic of Moldova, as in the case of Romania is a fundamental right. According to article 9 para. (1) Property can be public and private. Para. (2) provides that property is constituted of material and intellectual goods. This aspect is different from the Romanian Constitution because it does not regulate this differentiation. According to article 455 para. (1) of the Civil Code "Goods are all the things susceptible to individual or collective closeness and patrimonial rights. (2) Things are the corporeal objects in relation to which civil rights and obligations may exist. According to article 459 para. (1) of the Civil Code" Property can be immovable or movable, thereinafter regulating which property is immovable and which movable.

At the same time, the Civil Code of the Republic of Moldova defines which objects constitute intellectual property. According to article 476 para. (1) of the Civil Code: "Any result of the intellectual activity, confirmed and protected by the corresponding rights regarding its use, is considered an object of intellectual property. (2) The objects of intellectual property are divided into two categories: a) objects of industrial property (inventions, plant varieties, topographies of integrated circuits, trademarks, industrial designs, geographical indications, denominations of origin and guaranteed traditional specialties); b) objects of copyright (literary, artistic and scientific works, etc.) and related rights (interpretations, phonograms, videograms and broadcasts of broadcasting organizations, etc.). (3) In the field of intellectual property, other assets have a separate regulatory system, such as: a) trade secret (know-how); b) trade name".

Intellectual property is a particular kind of property. In some people's opinion, it is a "creation of one's own." This creation property is the fusion of two facets:

1) Dominium emines, that is the property that, after the appearance of the work, the invention, etc., the entire community; 2) Useful Domminium, that is the property owned by the person through whose creative work it was possible to appear the work, invention, etc., a person who from the time of the appearance of the product of the respective divine work a simple holder to exploit and use the work, the invention, etc. that he created ${ }^{1}$.

According to article 33 of the Constitution of the Republic of Moldova regarding the freedom to create "The right of citizens to intellectual property, their material and moral interests related to various types of intellectual creation shall be protected by the law."

Similarly, as in the Constitution of Romania, the Constitution of the Republic of Moldova guarantees the right of private property through the prism of article 46 Right to Private Property and Its Protection. Para. "(1) The right to possess private property

${ }^{1}$ S. Mămăligă, Copyright and related rights, ARC Publishing House, Chișinău, p. 27.

CONSTITUTIONAL LAW REVIEW 
and the debts incurred by the State are guaranteed. (2) No one may be expropriated except for a matter of public utility, as established by the law, against a fair and previously determined compensation. (3) No assets legally acquired may be seized. The legal nature of the acquirement of assets is presumed."

According to the Decision of the Constitutional Court of the Republic of Moldova on the control of the constitutionality of some provisions of the Criminal Code and the Criminal Procedure Code (extended confiscation and illicit enrichment) of April 15, $2016^{2}$, para. 41: "The provision establishing the presumption of the legal character of the acquisition of the property constitutes a fundamental element of the of article 46 para. (4) of the Constitution of the Republic of Moldova: "The assets intended for, used or resulted from misdemeanors or offences shall be seized only according to the law." This presumption, ensuring the legal certainty and legality of the person's property, implies the responsibility of the authorities to present evidence that would prove the illegality of acquiring the property. This constitutional guarantee is an application of the principle of the presumption of innocence, enshrined in the Constitution and in the unconstitutional acts of the Republic of Moldova, as well as in the international human rights instruments.

Given that, the presumption instituted by the constitutional text of reference does not impede, de plano, confiscation of the assets acquired illegally. The legislator cannot adopt a regulation, by which the task of evidence would be overturned in this regard, since such regulation would be unconstitutional, it can though regulate the evidence system in such a manner that it would enable the concerned parties to lodge evidence that would contradict the presumption instituted by the constitutional text.

The Venice Commission in one of its reports ${ }^{3}$ has underlined importance of the precise legislation in the field of evidence, which must be observed by the authorities to perform confiscation of the assets in the view of avoiding that such confiscation would be an unjustified interference in the exercise of the property right. This precision is a source of uniformity; it ensures safety and legal predictability and it guarantees meanwhile that the provisions governing the procedure of confiscation emanates from the legislative power and not from the judicial one, which constitutes an indispensable aspect especially in the countries affected by the corruption ${ }^{4}$.

As regards the public property, as well as the Constitution of Romania, the Constitution of the Republic of Moldova regulates which one is this by article 127

${ }^{2}$ Decision of the Constitutional Court of the Republic of Moldova on the control of the constitutionality of some provisions of the Criminal Code and the Criminal Procedure Code (extended confiscation and illicit enrichment) of April 15, 2016.

3 „Avis interimare sur le projet de loi relative a la confiscation en faveur de l etat des biens acquis illegalement de la Bulgarie" - adopted by the Commission at the 82nd plenary session, Venice, 12-13 March 2010.

${ }^{4} \mathrm{M}$. Safta, Presumption of lawful acquisition of assets and confiscation of illicit assets acquired in the case law of the Constitutional Court of Romania. The constitutional frame of reference for the regulation of the extended confiscation, p. 121, http://www.tribunajuridica.eu.

STUDIES AND ARTICLES 
para. (3) "Public property shall belong to the State or to the territorial-administrative units. (4) All the underground resources, airspace, waters and forests used to the benefit of the public at large, natural resources of the economic regions and continental shelf, lines of communication, as well as other assets stipulated by law, shall constitute the exclusive objects of public property." and establishes in article 127 para. (1) and (2) that the State shall protect the property. The State shall guarantee to everyone the right to possess property in forms as requested by the owner, as long as these forms do not conflict with the interests of society.

Another important aspect is that by the Constitution, article 128 para. (1) in the Republic of Moldova: "the property of foreign states, international organizations, foreign citizens and stateless persons shall be protected by the law".

\section{Control of the constitutionality of the incriminating norms of the crimes}

\section{against the property stipulated in the Criminal Code of the Republic}

\section{of Moldova}

In the Republic of Moldova, as well as in Romania, the only constitutional jurisdiction authority ${ }^{5}$ is the Constitutional Court, which at the referral exercises, upon appeal, the review of constitutionality over laws and decisions of the Parliament, decrees of the President, decisions and ordinances of the Government, as well as over international treaties to which the Republic of Moldova is a party, gives the interpretation of the Constitution ${ }^{6}$, as well as exercises other powers.

Therefore, the Constitutional Court is the fist and main interpreter of the fundamental Law, but by its obligation of interpretation, it ensures its development and that of the constitutional law. Whenever it checks whether an infraconstitutional norm complies with the Constitution, the Constitutional Court and the authorities of constitutional jurisdiction performs in the necessary manner an official interpretation of the Constitution, meaning that it explains and develops the constitutional principles and norms and determines that it should remain a "vivid law"7. At the same time, in the plastic expression, "the constitutional court makes law by interpreting the Constitution", to the effect that decisions that are delivered may be attributed the quality of "normative force", thanks to their general obligatory character ${ }^{8}$.

${ }^{5}$ Law no. 502 of 16.06 .1995 regarding the Code of constitutional jurisdiction, published on 28.09.1995, in Official Gazette no. 53-54, art. No.: 597.

${ }^{6}$ Law no. 137 of 13.12 .1997 regarding the Constitutional Court, published in Official Gazette no. 8 art. No.: 86 on 07.02 .1995 .

7 T. Toader, M. Safta, Development of Constitutionalism in Romania, in Journal of Constitutional Law no. 1/2015, p. 199.

${ }^{8}$ Ibidem. 
When carrying out an analysis of the acts of the Constitutional Court of the Republic of Moldova regarding the referrals of the constitutionality control of the incriminating norms of crimes against property, there has been observed a smaller volume of referrals, respectively decisions or rulings. This may be due to the fact that, prior to the adoption of Decision no. 2 of 09.02.2016 ${ }^{9}$, the Constitutional Court of the Republic of Moldova could be applied to only through the Supreme Court of Justice of Moldova, which could do a preliminary control of the constitutionality of some legal norms and had the possibility to reject these referrals $a b$ initio, without being subjected to control by the Constitutional Court.

Thus, by Decision no. 2 of 09.02.2016 of the Constitutional Court regarding the interpretation of article 135 para. (1) cl. A) and g) of the Constitution of the Republic of Moldova (the exception of unconstitutionality) it was decided that the exception of unconstitutionality can be raised before the court directly to the Constitutional Court by either party or its representative, as well as by the court ex officio, and the ordinary judge is not allowed to set out on merits, confining himself exclusively to the verification of the fulfillment of the following conditions: (1) the object of the exception falls within the category of the acts included in article 135 para. (1) cl. A) of the Constitution; (2) the exception is raised by one of the parties or its representative, or indicates that it is raised by the ex officio court; (3) the contested provisions are to be applied in the settlement of the case; (4) there is no previous judgment of the Court regarding the disputed provisions.

In the Criminal Code of the Republic of Moldova crimes against property are regulated in Chapter VI, including 19 crimes, whose object of the referral regarding the exception of unconstitutionality made the incriminating norm of blackmail and fraud, several times, under various aspects.

Thus, by referrals to the Constitutional Court no. $144 \mathrm{~g} / 2019$ regarding the exception of unconstitutionality of article 189 para. (3) cl. E) of the Criminal Code (the blackmail resulted in the acquisition of certain goods the author claims that the text of article 189 para. (3) cl. E) of the Criminal Code - "followed by the acquisition of the requested goods" the author invoked that this - contravenes the legal nature of blackmail, because in the context of blackmail the value of the assets acquired by the offender does not matter, as a result of the crime in question.

Pursuant to para. (1) of Article 189 of the Criminal Code, the offence of blackmail is: (1) Blackmail, meaning the demand to transfer an owner's, possessor's or holder's property or his/her right to this property or to accomplish other actions of a property character threatening with violence against the person, relatives or their close persons, or threatening with disclosure of defaming information about these persons, or with

9 Decision of the Constitutional Court of the Republic of Moldova no. 2 of 09.02.2016 for the interpretation FOR article 135 para. (1) cl. a) and g) of the Constitution of the Republic of Moldova (exception of unconstitutionality) (Referral no. 55b / 2015). 
damaging or destroying the assets of the owner, possessor, holder or with kidnapping the owner, possessor, holder, of their relatives or close persons, shall be punished by a fine in the amount of 750 to 950 conventional units or jail sentence of 3 to 5 years. (2) Blackmail committed: a) excluded; b) by two or more persons; c) using violence which does not endanger life or health; d) involving threat of murder; e) involving damage or destruction of assets; $f$ ) against the donators of political parties or of election competitors shall be punished by jail sentence of 5 to 7 years with a fine in the amount of 850 to 1350 conventional units. (3) Acts provided by paragraphs (1) or (2): a) committed by an organized criminal group or criminal organization; b) committed by use of weapons or other objects used as weapons; $c$ ) involving the use of violence endangering life and health; d) involving particular cruelty; e which resulted in other serious consequences, shall be punished by jail sentence of 7 to 10 years with a fine in the amount of 1850 to 2350 conventional units..."

Examining the referral to the Constitutional Court by decision of 12.09.2019 declared it inadmissible, reasoning that "The acquisition of goods as a result of blackmail constitutes a situation that gives the crime in question a more prominent degree of prejudice. For this reason, it is natural that the blackmail resulted in the acquisition of goods be punished more harshly than the blackmail that did not involve the production of such consequences. Eventually, the courts are to individualize in each particular a penalty that is to be applied on a person by taking in consideration all relevant circumstances ${ }^{\prime 10}$. Therefore, the components of the offence of blackmail are realized, regardless the satisfaction of the offender's demands ${ }^{11}$. Since this a complex offence, there is a secondary circumstance that may be - as to the secondary legal object - a physical suffering or harm to the body integrity, or property damage, or harm to other non-property interests of the person ${ }^{12}$. Given that, the offence of blackmail is a formal offence. It is considered to be consumed from the time of making a demand accompanied by the adjacent action, regardless whether the offender has achieved their aim or not. The exception to this rule is the aggravated modes of blackmail given in lit. e) from para. (2) and from lit. e) and f) from para. (3) of Article 189 of the Criminal Code of the Republic of Moldova. Considering these assumptions, blackmail is considered to be consumed from the time of appearance of the actual property damage or respectively from the time of occurrence of other serious consequences ${ }^{13}$.

Regarding the blackmail, but in another aspect, by referral no. $153 \mathrm{~g} / 2018$ the exception of unconstitutionality of some provisions of article 189 para. (1) of the

${ }^{10}$ Decision of 12.09 .2019 of the Constitutional Court of inadmissibility of the referral no. $144 \mathrm{~g} / 2019$ regarding the exception of unconstitutionality of article 189 para. (3) lit. e) of the Criminal Code (blackmail resulting in the acquisition of certain goods).

${ }^{11}$ V. Dongoroz and collaborators, Theoretical explanations of the Romanian Criminal Code, Volume I, II edition, Romanian Academy All Beck Publishing House, Bucharest, 2003, p. 154.

12 V. Cioclei, Criminal law, the Special Party, Publishing house C. H. Beck, p. 154.

${ }^{13}$ S. Brânză, X. Ulianovschi, V. Stati, V. Grosu, I. Țurcanu, Criminal law, the Special Party, Cartier Juridic Publishing House, Chișinău, 2005, p. 294. 
Criminal Code (the blackmail committed by threatening to spread defamatory news) was declared. By this, the authors invoked that the text "threatening [...] with the spread of defamatory news about them" in article 189 para. (1) of the Criminal Code is unpredictable and allows an extensive interpretation unfavorable one to the accused. The authors of the complaint mentioned that, in the case where the exception of unconstitutionality was raised, the request for a sum of money by threatening to denounce to the law enforcement bodies some illegal acts was classified as a blackmail crime committed by threatening to spread defamatory news about the victim. According to the authors, this interpretation is an extensive and unfavorable one for the accused, because denouncing illegal acts is a person's right and, therefore, threatening to disclose such information cannot be described as spreading the defamatory news about the alleged victim.

In examining the exception of unconstitutionality, the Constitutional Court retained that: "indeed, the concept of "defamatory news" is not defined in the criminal law. However, in view of the particularities of the blackmail, the legislature did not regulate the specific ways of "spreading defamatory news", thus avoiding, unjustifiably, restricting the scope of the provisions of article 189 of the Criminal Code. Threatening with disclosure of defaming information represents arousing fear that the offender will divulge some compromising information on the owner, possessor, holder, on their relatives or close persons, in case the owner, possessor or holder does not fulfill the demand. Defaming news is true or false information, divulgation of which may affect to the person's honor and dignity (for example, information on crimes committed, on sexually transmitted or mental diseases the person suffers from, on other shameful facts from the biography etc.). Deliberate spreading of some defaming nens of false character is not included in the provision of Article 189 para. (I) of the Criminal Code, and is to be qualified pursuant to Article 70 of the Code of Administrative Offences ${ }^{14}$.

In the doctrine, in general, it is appreciated that the guilt required for the existence of the blackmail crime is presented in the form of the direct intention qualified by the purpose pursued by the perpetrator, respectively the unjust acquisition of a benefit, for himself or for another ${ }^{15}$.

The Court notes that the criminal law cannot excel in explanatory texts. In view of the principle of general applicability of the laws, the European Court of Human Rights held that their formulation cannot be absolutely accurate. No matter how clearly a legal rule is drafted, in any legal system, there is an inevitable element of judicial interpretation and in a criminal law rule as well. Again, although certainty is desirable, it may result in excessive rigidity. The decision-making role conferred on the courts seeks

\footnotetext{
${ }^{14}$ Decision of the Plenary of the Supreme Court of Justice of the Republic of Moldova, regarding the judicial practice in criminal trials regarding blackmail no.16 of 07.11.2005.

15 V. Cioclei, Criminal law. Special Part, C. H. Beck Publishing House, Bucharest, p. 154.
} 
precisely to eliminate the doubts that persist when interpreting the rules (Del Rio Prada v. Spain [MC], October 21, 2013, \& 92 and §93; Rohlena v. Czech Republic [MC], January $27,2015, \S 50)$ ", and therefore the decision declared the complaint as inadmissible ${ }^{16}$.

In this regard, loan Vida, the ex-President of the Constitutional Court of Romania has underlined that "exclusion of the Court's possibility to provide an opinion on the actual situations has proven to be an instrument of delimiting between the courts and the Constitutional Court, so that the courts would be able to deliver justice and in the competence of the administrative court the aptitude to decide on the issues of law issues that are about determining their understanding against the Constitution"17.

Although the constitutional law does not contain any express regulations, by which application of the case law of the European Court of Human Rights in the national constitutional jurisprudence would be imposed, since the ECHR case law is an integral part of the provisions of the European Convention, the necessity of taking it in consideration results from the provisions of para. (2) of Article 4 in the Constitution, according to which: "The constitutional provisions on the human rights and liberties are interpreted and applied in accordance with the Universal Declaration on Human Rights, with the pacts and other treaties, to which the Repubic of Moldova is a party."

In the case law of the Constitutional Court, the most numerous decisions are those, by which the solutions were provided that have been based besides the constitutional norms on the provisions of the Convention and the case law of the European Court, in such fields as infringement of the property right, principles of equality and non-descrimination, right to defence, free access to justice, fair trial resolved within a reasonable period of time, freedom of assembly and association ${ }^{18}$.

By the decision of inadmissibility of the Constitutional Court of the Republic of Moldova of referral no. $152 \mathrm{~g} / 2018$ regarding the exception of unconstitutionality of some provisions of article 190 para. (1) of the Criminal Code the following were established:

According to article 190 para. (1) of the Criminal Code: "Scam, that is, illicit acquisition of the property of another person by misleading one or more persons through presenting a false fact as true or a true fact as a lie, regarding the nature, substantial qualities of the object, to the parties (if their identity is the determining reason for the conclusion of the legal act) of the null or cancelable legal act, or if its conclusion is determined by the malicious or cunning behavior that has caused considerable damage".

16 Decision of the Constitutional Court of November 15, 2018 on inadmissibility of referral no. 153g/ 2018 regarding the exception of unconstitutionality of some provisions of article 189 para. (1) of the Criminal Code (the blackmail committed by threatening to spread defamatory news).

17 T. Toader, M. Safta, Development of Constitutionalism in Romania, in „Journal of Constitutional Law” no. $1 / 2015$, p. 169.

${ }^{18}$ Report of the Constitutional Court of the Republic of Moldova to the XVI Congress of the Conference of the European Constitutional Courts (Vienna, May 2014), p. 6.

\section{CONSTITUTIONAL LAW REVIEW}


On October 15, 2018, Judge Victor Sandu from the Chisinau Court, Centru District, raised the exception of unconstitutionality of the text "regarding the nature, substantial qualities of the object, to the parties (if their identity is the determining reason for the conclusion of the legal act) of the null or cancelable legal act, or if its conclusion is determined by the malicious or cunning behavior that has caused considerable damage" in article 190 para. (1) of the Criminal Code.

In the reasoning of the complaint, the author claimed that the contested provisions of article 190 para. (1) of the Criminal Code are unpredictable and therefore allow an extensive interpretation which is unfavorable to the accused. In describing the elements of the fraud, the legislator operates with notions of the civil law, which are not defined. The application of article 190 of the Criminal Code is conditioned by the existence of a legal act is void, concluded by the vitiation of the consent. In these circumstances, it is not clear whether the judge examining a criminal case for indictment under Article 190 of the Criminal Code must consider the findings of a civil court on the invalidity of the legal act or whether it should substitute a civil court and find first if the legal act is void. According to the author, the legislature has created an overlap between civil liability (sanction for invalidity of the legal act) and criminal liability, although these types of liability must be strictly delimited. The contested provisions create the risk that any non-performance of civil obligations will be qualified on the basis of article 190 of the Criminal Code, contrary to article 1 of Protocol no. 4 to the European Convention on Human Rights, which provides that no one shall be deprived of his liberty merely on the ground of inability to fulfil a contractual obligation. According to the author of the exception of unconstitutionality, the contested provisions contravene the articles 1 para. (3), 22 and 23 of the Constitution.

When examining the complaint, the Court found that: the text "misleading one or more persons through presenting a false fact as true or a true fact as a lie, regarding the nature, substantial qualities of the object, to the parties (if their identity is the determining reason for the conclusion of the legal act) of the null or cancelable legal act, or if its conclusion is determined by the malicious or cunning behavior" leads to the idea that the victim's consent is vitiated at the time of the conclusion of the legal act by fraudulent maneuvers committed with intent by the perpetrator of the crime. The perpetrator creates a false representation of reality to the victim.

Thus, the Court does not retain that any non-performance of civil obligations is qualified under Article 190 of the Criminal Code. Failure to perform the obligations arising from a concluded contract cannot be classified as a fraudulent offense unless it has been established that fraudulent maneuvers were used against the creditor of the obligation until and for the conclusion of the contract. In this regard, the applicability of Article 1 of Protocol no. 4 to the European Convention on Human Rights may not be affirmed. Also, the Court did not find that the legislature generated an overlap between civil liability (sanction for invalidity of the legal act) and criminal liability, motivating as follows: "It is true that the conditions under which the fraud can be imputed are similar 


\section{Corina STRATAN}

to the cases of invalidity of the contract vitiated by error and of the contract concluded by false pretences, provided for in articles 227 and 228 of the Civil Code. However, there are differences between these institutions. The error as a defect of consent can also be invoked if both parties had a misrepresentation of the circumstances at the time of conclusion of a legal act, as well as if a co-contracting party was in error for objective reasons, not necessarily from the cause of its misleading. However, in the case of the scam, the subjective element of this offense is the direct intention. The author is aware that he is misleading and that by doing so he causes damage, in order to achieve an unjust material application (intent qualified by purpose)." The court also mentioned that the fraud has similarities with the institution of civil false pretences, which also implies a misleading. The difference is in the fact that, in the case of the scam, the author seeks to obtain a profit at the expense of another person's property, and not the mere breach of consent to cause a person to conclude a legal act. Thus, the task of ascertaining whether the act imputed to the person constitutes a "criminal deception" is incumbent upon the judge who judges the criminal case. Also, taking into account the fact that in such cases a civil action is usually brought, the judge who judges the criminal case can cancel the legal act concluded by false pretenses and can restore the situation prior to the conclusion of the contract. The court declares that it is not necessary for a civil court to establish the invalidity of the legal act concluded through false pretenses in order to set up a criminal case. In view of the above, the Court found that the unconstitutionality exception is unfounded ${ }^{19}$. The objective side of the offence of fraud is carried out that the offender creates to the victim a false representation of the reality, regardless the means used in this regard. If the used means is fraudulos, the offence is more serious, but if it meets the component elements of the distinct offence, concurrent offences will take place ${ }^{20}$.

In conclusion, the role of the Constitution of Romania, of the Republic of Moldova, as well as of the Constitutional Courts of both states in the defense of the property right is fundamental, both by guaranteeing this right by the higher law, and by ensuring and verifying the constitutionality of the incriminated law norms of offenses against property. As a consequence, the detection of unconstitutionality of a criminal law has the effect of decriminalizing this fact, which can lead to an optimal solution in the realization of the right of defense of a person accused of committing that criminal act.

${ }^{19}$ Decision of inadmissibility of the Constitutional Court of the Republic of Moldova of referral no. 152g/ 2018 regarding the exception of unconstitutionality of some provisions of Article 190 para. (1) of the Criminal Code.

20 T. Toader, Drept penal. Partea specială, Hamangiu Publishing House, Bucharest, p. 212. 